\title{
EFFECTS OF MICRONUTRIENTS ON SEED YIELD AND OIL CONTENT OF BRASSICA NAPUS L. CV. TALAYEH
}

\author{
Abdollah Bahrani* and Jafar Pourreza \\ Department of Agriculture, Ramhormoz Branch, Islamic Azad University, Ramhormoz, Iran \\ Key words: Canola, Foliar application, Grain yield, Nutrient elements, Oil yield
}

\begin{abstract}
Foliar application of micronutrients like iron, zinc and manganese significantly increased 1000-kernel weight, grain yield, oil content of seed and harvest index of Brassica napus L. cv. Talayeh. Changes in grain yield was primarily due to the number of pod per plant and that of oil yield was due to grain yield. In general, applying two parts per thousand of the micronutrient was the best treatment to obtain high qualitative and quantitative yield in cv. Talayeh in this region.
\end{abstract}

Canola (Brassica napus L.) is an important oil crop, ranking third only to soybean and palm oil in global production (Muhammad et al. 2007). Recent research has shown that a small amount of nutrients, particularly $\mathrm{Zn}, \mathrm{Fe}$ and $\mathrm{Mn}$ applied by foliar spraying significantly increased the yield of crops (Sarkar et al. 2007, Wissuwa et al. 2008). Narimani et al. (2010) reported that foliar application of microelements improved the effectiveness of macronutrients. Foliar application of microelements is more beneficial than soil application. Since application rates are lesser as compared to soil application, same application could be obtained easily and crop reacts to nutrient application immediately (Zayed et al. 2011). Arif et al. (2006) found that based on soil properties, foliar spraying could be effective 6 to 20 times as compared to soil application. Resistance to different stresses will be increased by foliar application of micronutrients (Ghasemian et al. 2010, Cakmak 2008). Therefore, the objective of this study was to ascertain the optimum level of some micronutrient as foliar application for higher grain yield and oil content of canola.

The studies were conducted in an arid area in west of Iran, at the Islamic Azad University of Ramhormoz, Khuzestan, Iran ( $31^{\circ} 16^{\prime} \mathrm{N}, 4^{\circ} 36^{\prime} \mathrm{E}$ and $150.5 \mathrm{~m}$ above the sea level) during $2012-$ 2013. Iron, zinc and manganese were sprayed on leaves of plants with concentration of two parts per thousand and four parts per thousand. Foliar application of micronutrient was done two times, at first when plants had 6 or 8 leaves and second treatment was applied when these had 10 or 12 leaves (early of flowering stage). To avoid the effect of micronutrient spraying, the plots were separated by borders of $1.5 \mathrm{~m}$ in width from all sides. The cv. Talayeh of Brassica napus used in this experiment. NPK were added at the rate of $150 \mathrm{~kg} \mathrm{~N} /$ fed as urea $46 \% \mathrm{~N}, 70 \mathrm{~kg} \mathrm{P}_{2} \mathrm{O}_{5} /$ fed as simple superphosphate $25 \% \mathrm{P}_{2} \mathrm{O}_{5}$ and $50 \mathrm{~kg} \mathrm{~K} \mathrm{~K}_{2} \mathrm{O} /$ fed as potassium sulphate $48 \% \mathrm{~K}_{2} \mathrm{O}$ before sowing. Plots were sown on 2 November 2012 with a cone seeder, and were $6 \mathrm{~m}$ long and $2.4 \mathrm{~m}$ wide, with 12 rows $0.2 \mathrm{~m}$ apart. At maturity, 10 plants were taken randomly from each sub plot for recording the morphological characteristics, yield components and grain yield. The various parameters within the rapeseed plant that are discussed in this paper were evaluated as follows: Specific seed weight (average weight of 1000 seeds in grams); recorded on ten random samples from each sub-plot. Seed yield: Center eight rows (of 12 rows) of each plot were harvested for grain yield, and converted to grain yield per hectares. Harvest index: [wt. of grain/ (wt. of grain + straw)]. The oil concentration of a sample of whole seeds from each plot was determined by

*Author for correspondence: <abahrani75@yahoo.com>. 
Near-infrared reflectance spectroscopy as described by Bhatty (1991). Oil yield (kg/ha); calculated by multiplying seed oil percentage $\times$ seed yield per ha. Samples were dried in a forced-air oven at $70^{\circ} \mathrm{C}$ for $48 \mathrm{hrs}$. Data were analyzed by analysis of variance. When significant differences were found $(p=0.05)$ among means, Duncan's multiple range test (DMRT) were applied.

The highest number of pod per plant was related to two parts per thousand $\mathrm{Fe}, \mathrm{Zn}$ and $\mathrm{Mn}$ and the lowest number of pod per plant belonged to the zero micronutrients (Table 1).

Foliar application of $\mathrm{Fe}, \mathrm{Zn}$ and $\mathrm{Mn}$ on number of seed per pod was not significant. However, the highest number of seed per pod was obtained at application of four parts per thousand (Table 1).

$\mathrm{Fe}, \mathrm{Zn}$ and $\mathrm{Mn}$ had significant effect on kernel weight at $5 \%$ probability level. Two and four parts per thousand $\mathrm{Fe}, \mathrm{Zn}$ and $\mathrm{Mn}$ produced the greatest values of kernel weight (Table 1). Narimani et al. (2010) indicated that foliar application of $\mathrm{Zn}, \mathrm{Mg}, \mathrm{Mn}$ and $\mathrm{Fe}$ significantly increased growth parameters, yield of durum wheat. Zeidan et al. (2006) found that foliar spray of micronutrients considerably enhanced the number of pods per plant, 1000-seed weight and seed yield.

Foliar application of four parts per thousand $\mathrm{Fe}, \mathrm{Zn}$ and $\mathrm{Mn}$ produced the highest grain yield (Table 1). SeifiNadergholi et al. (2011) stated that foliar application with manganese sulphate increased seed yield of plants.

There was significant difference between foliar application of $\mathrm{Fe}, \mathrm{Zn}$ and $\mathrm{Mn}$ treatments in harvest index. Four parts per thousand Fe, $\mathrm{Zn}$ and $\mathrm{Mn}$ was more successful than other treatments to produce higher harvest index (Table 1). Ghasemian et al. (2010) reported significant positive effect of zinc treatment on dry matter, seed and straw yield of soybean.

Table 1. Foliar effects of Fe, Zn and Mn on grain and oil yield of Brassica napus cv. Talayah.

\begin{tabular}{ccccccccc}
\hline Treatments & $\begin{array}{c}\text { No. of } \\
\text { pod per } \\
\text { plant }\end{array}$ & $\begin{array}{c}\text { No. of } \\
\text { seed per } \\
\text { pod }\end{array}$ & $\begin{array}{c}1000-\text { kernel } \\
\text { weight } \\
(\mathrm{g})\end{array}$ & $\begin{array}{c}\text { Grain } \\
\text { yield } \\
\mathrm{kg} / \mathrm{ha}\end{array}$ & $\begin{array}{c}\text { Biological } \\
\text { yield } \\
\mathrm{kg} / \mathrm{ha}\end{array}$ & $\begin{array}{c}\text { Harvest } \\
\text { index } \\
(\%)\end{array}$ & $\begin{array}{c}\text { Oil } \\
(\%)\end{array}$ & $\begin{array}{c}\text { Oil yield } \\
\mathrm{kg} / \mathrm{ha}\end{array}$ \\
\hline \multicolumn{2}{l}{ Foliar application of Fe, Zn, Mn part per thousand } \\
0
\end{tabular}

Same letters in columns are not significantly different at $\mathrm{p} \leq 0.05$.

Four parts per thousand of $\mathrm{Fe}, \mathrm{Zn}$ and $\mathrm{Mn}$ produced the highest oil seed and oil seed yield (35 and $51 \%$ ). Oil content is typically characteristic of species, variety and their genetic make up. Application of $\mathrm{Zn}$ or $\mathrm{Fe}$ caused significant positive effects, in most cases, on growth measurements and chemical composition (Ghasemian et al. 2010, Nasiri et al. 2010).

The results of correlation coefficients between traits showed that grain yield had a positive and significant correlation with oil yield and biological yield at $1 \%$ probability levels, oil yield also had positive correlation to oil percent. Negative correlation also was observed between number of pod per seed and 1000-kernel weight (Table 2). 
Table 2. Simple correlation coefficients between traits.

\begin{tabular}{lccccccc}
\hline Factor & 1 & 2 & 3 & 4 & 5 & 6 & 7 \\
\hline 1-number of pod/plant & & & & & & & \\
2-number of seeds/pod & -0.023 & & & & & & \\
3-1000-kernel weight & -0.05 & $-0.746^{* *}$ & & & & & \\
4-biological yield & 0.477 & 0.078 & 0.172 & & & & \\
5-grain yield & 0.581 & 0.203 & 0.082 & $0.81^{* *}$ & & & \\
6-oil per cent & -0.064 & -0.087 & 0.084 & 0.164 & 0.102 & & \\
7-harvest index & 0.521 & 0.01 & 0.079 & 0.015 & 0.58 & -0.073 & \\
8-oil yield & 0.484 & 0.171 & 0.19 & 0.238 & $0.884^{* *}$ & $0.637^{*}$ & 0.029 \\
\hline
\end{tabular}

Results of correlation between traits also showed that changes on grain yield and oil yield were primarily due to changes in the number of pod per plant and grain yield, respectively.

\section{Acknowledgment}

Funds for this research was provided by the Islamic Azad University of Ramhormoz, Khuzestan, Iran.

\section{References}

Arif M, Chohan MA, Ali S, Gul R and Khan S 2006. Response of wheat to foliar application of nutrients. J. Agric. Biol. Sci. 1: 256-259.

Bhatty RS 1991. Measurement of oil in whole flaxseed by near-infrared reflectance spectroscopy. J. Am. Oil. Chem. Soc. 68: 34-38.

Cakmak I 2008. Enrichment of cereal grains with zinc: Agronomic or genetic biofortification? Plant Soil. 302: 1-17.

Ghasemian V, Ghalavand A, Soroosh A, and Pirzad A 2010. The effect of iron, zinc and manganese on quality and quantity of soybean seed. J. Phytol. 2:73-79.

Muhammad N, Cheema MA, Wahid MA, Ahmad N and Zaman M 2007. Effect of source and method of nitrogen fertilizer application on seed yield and quality of canola (Brassica napus L.). Pak. J. Agri. Sci. 44:74-78.

Narimani H, Rahimi MM, Ahmadikhah A and Vaezi B 2010. Study on the effects of foliar spray of micronutrient on yield and yield components of durum wheat. Arch. Appl. Sci. Res. 2: 168-176.

Nasiri Y, Zehtab-Salmasi S, Nasrullahzadeh S, Najafi N and Ghassemi- Golezani K 2010. Effects of foliar application of micronutrients $(\mathrm{Fe}$ and $\mathrm{Zn}$ ) on flower yield and essential oil of chamomile (Matricaria chamomilla L.). J. Med. Plants Res. 4: 1733-1737.

Sarkar D, Mandal B and Kundu MC 2007. Increasing use efficiency of boron fertilizers by rescheduling the time and methods of application for crops in India. Plant Soil. 301: 77-85.

SeifiNadergholi M, Yarnia M and Rahimzade F 2011. Effect of zinc and manganese and their application method on yield and yield components of common bean (Phaseolus vulgaris L. cv. Khomein). MiddleEast J. Sci. Res. 8: 859-865.

Wissuwa M, Ismail AM and Graham RD 2008. Rice grain zinc concentrations as affected by genotype native soil-zinc availability, and zinc fertilization. Plant Soil. 306:37-48.

Zayed BA, Salem AKM, and Sharkawy HM 2011. Effect of different micronutrient treatments on rice (Oriza sativa L.) growth and yield under saline soil conditions. World J. Agric. Sci. 7: 179-184.

Zeidan MS, Hozayn M and Abd El-Salam MEE 2006. Yield and quality of lentil as affected by micronutrient deficiencies in sandy soils. J. Appl. Sci. Res. 2: 1342-1345. 